\title{
UJI pH, KARAKTER FISIK DAN ORGANOLEPTIK PADA MANISAN BUAH MANGGA UDANG
}

\author{
Uswatun Hasanah, Shabri Putra Wirman, Sri Fitria Retnowaty, Aji Suroso \\ Program Studi Fisika, Fakultas MIPA dan Kesehatan \\ Universitas Muhammadiyah Riau
}

Email: uswatun.has02@gmail.com

\begin{abstract}
ABSTRAK
Buah mangga udang adalah salah satu varietas mangga yang merupakan buah musiman dengan rasa relatif lebih asam dibanding buah mangga jenis lain. Salah satu olahan mangga udang adalah manisan yang diawetkan menggunakan gula atau pemanis buatan. Oleh karena itu perlu dilakukan penelitian untuk mengetahui uji $\mathrm{pH}$, karakteristik fisis dan organoleptik (rasa) manisan buah mangga udang dengan penambahan pemanis buatan. Uji karakteristik fisis berupa massa jenis, viskositas, Oxidation Reduction Potential (ORP), Total Disolve Solid (TDS), Salinitas, Konduktivitas, Resistivitas. Hasil penelitian menunjukkan nilai $\mathrm{pH}$ terbaik terdapat pada sampel tanpa penambahan pemanis buatan yaitu 3,75. Dan pada hasil uji fisis, penambahan pemanis buatan mempengaruhi nilai massa jenis, ORP, dan konduktivitas, dengan masing-masing nilai $1202 \mathrm{~kg} / \mathrm{m}^{3}, 187 \mathrm{Mv}$ dan $376 \mathrm{Ohm}$. Kemudian untuk hasil uji rasa, smpel dengan penambahan pemanis buatan tidak disukai oleh para panelis.
\end{abstract}

Kata-kunci; Buah Mangga, Pemanis Buatan, Manisan, Uji pH, Uji Fisis

\section{PENDAHULUAN}

Indonesia kaya akan tanaman buah-buahan, salah satunya adalah mangga. Buah mangga (Mangfera indica 1) termasuk dalam golongan buah eksotis yaitu buah-buahan khas daerah tropis yang banyak disukai dan cocok bagi seluruh lapisan masyarakat. Buah mangga adalah tanaman populer yang terbesar di seluruh dunia. Mangga banyak dibudidayakan oleh masyarakat karena memiliki nilai komersial yang tinggi. Mangga memiliki kandungan gizi tinggi yang diperlukan bagi tubuh dan dapat menanggulangi masalah defesiensi vitamin $\mathrm{C}$ di Indonesia. Didalam mangga terdapat rasa manis yang bervariasi sesuai dengan jenis varietasnya [1,2].

Buah mangga udang adalah salah satu varietas mangga yang merupakan buah musiman, dimana produksinya akan melimpah pada musim panen. Umur simpannya sangat pendek karena merupakan bahan pangan yang mudah rusak atau membusuk dalam jangka waktu tertentu. Selain itu rasanya relatif lebih asam dibanding buah mangga jenis lain, sehingga jarang disukai oleh masyarakat. Produksi buah mangga udang sangat melimpah pada musim panen sedang jangka waktu simpannya sangat pendek serta rasanya relatif asam. Maka dari itu perlu mengolahnya menjadi produk olahan makanan yang dapat dikonsumsi setiap saat dan dapat membuat rasanya lebih enak. Dan olahan makanan yang dapat dibuat adalah dengan mengolahnya menjadi manisan $[1,2]$.

Manisan buah adalah buah yang diawetkan menggunakan gula dengan kadar yang tinggi. Selain itu juga untuk mencegah tumbuhnya mikroorganisme seperti jamur dan kapang. Prinsip pembuatan manisan adalah proses peresapan larutan gula sampai kadar gula di dalam bahan pangan cukup tinggi. Kadar gula yang demikian akan menghasilkan tekanan osmosis yang tinggi. Namun dengan berkembangnya zaman banyak orang mengganti gula dengan pemanis buatan. Tujuan dari penambahan dari pemanis buatan selain agar lebih manis juga untuk mendapatkan nilai ekonomis yang lebih tinggi $[3,4]$.

Beberapa penelitian tentang uji $\mathrm{pH}$ dan uji fisis telah dilakukan dengan berbagai macam buah diantaranya yang telah dilakukan Ferida Sulistyaningrum yang menganalisis sifat fisik 
dan organoleptik keripik buah mangga (Mangifera indica l.) produk olahan vacuum frying. Kemudian oleh Mariance Rince yang menganalisis sifat fisik dan organoleptik pada sari wortel. Dan oleh Dwiyanti yang menganalisa sifat antioksidan, sifat kimia dan sifat fisik manisan basah dari kunyit putih $[1,5,6]$.

Pada penelitian ini dilakukan uji karateristik fisis, $\mathrm{pH}$ dan organoleptik dari manisan buah mangga udang dengan penambahan pemanis buatan. Uji karakteristik fisis yang dilakukan yaitu berupa massa jenis, viskositas, Oxidation Reduction Potential (ORP), Tottal Disolve Solid (TDS), Salinitas, Konduktivitas, Resistivitas, dan uji organoleptik berupa uji rasa.

\section{METODOLOGI PENELITIAN}

Alat

Alat yang digunakan untuk pembuatan manisan mangga udang antara lain pisau, panci, saringan, sendok makan, sendok teh, kantung plastik dan baskom. Sementara alat yang digunakan untuk melakukan uji $\mathrm{pH}$ dan fisis, diantaranya $\mathrm{pH}$ meter, ORP meter, Conductivity meter, viskometer ostwald, pipet tetes, gelas ukur dan neraca digital.

\section{Bahan}

Bahan yang digunakan antara lain $5 \mathrm{~kg}$ mangga udang, $3,25 \mathrm{~kg}$ gula pasir, 500 gram garam, 10 liter air bersih, 16 gram pemanis, 5 gram pewarna, aquades, dan tissue

\section{Prosedur Kerja}

\section{Pembuatan Manisan Mangga}

Gambar 1 menunjukkan proses dari pembuatan manisan mangga udang.

Kupas lalu cuci mangga hingga bersih lalu iris-iris mangga, larutkan garam dalam air kemudian rendam mangga dalam larutan garam 4 jam, setelah itu mangga diangkat dan tiriskan, kemudian membuat larutan perendam yang terdiri dari gula dan pemanis buatan yang dilarutkan dalam air 2 liter, aduk larutan hingga tercampur rata, rendam mangga pada larutan tersebut selama 24 jam. Dengan variasi gula, pemanis, air, garam dan pewarna seperti pada Tabel 1.

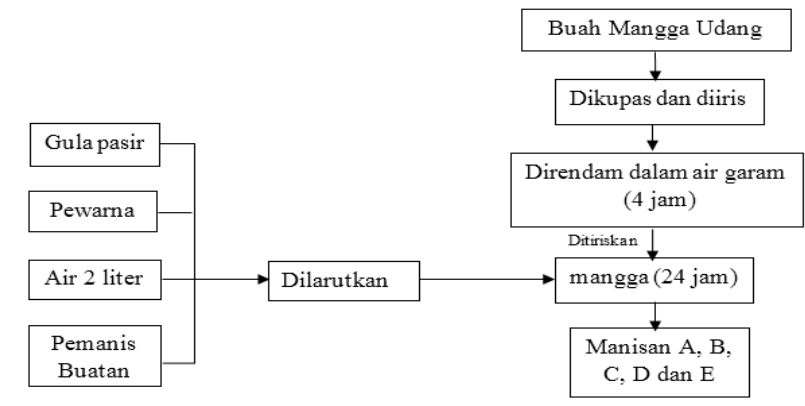

Gambar. 1. Diagram Alir Pembuatan Manisan Mangga

Tabel. 1. Variasi manisan mangga udang

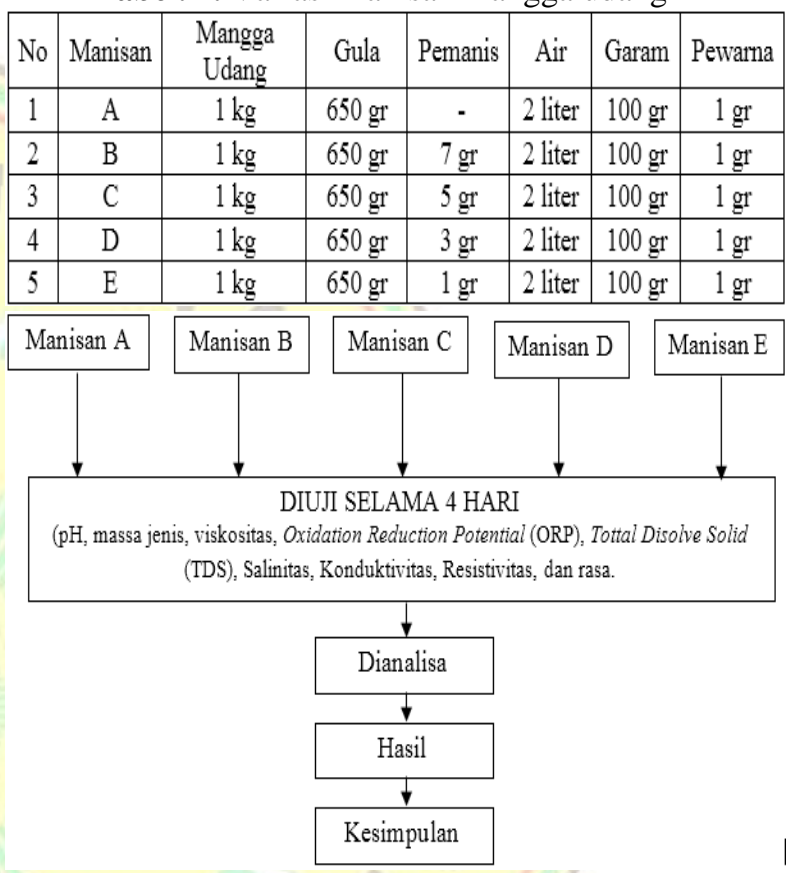

Gambar. 2. Diagram Alir Penelitian

Masing-masing variasi sampel manisan pada tabel teresebut dimasukan ke dalam 4 botol sebanyak $50 \mathrm{ml}$ setiap botol untuk pengujian selama 4 hari. Dimana untuk setiap pengujian digunakan 1 sampel (botol) untuk setiap 1 variasi manisan mangga.

Gambar 2. menunjukkan alir dari penelitian ini, dimana pada setiap sampel manisan akan diuji fisis dan $\mathrm{pH}$ serta organoleptik.

\section{Uji pH}

Uji $\mathrm{pH}$ dilakukan dengan cara menggunakan alat $\mathrm{pH}$ meter. $\mathrm{pH}$ meter yang digunakan dalam penelitian ini memiliki dua bagian, yaitu layar penampil dan probe pendeteksi nilai $\mathrm{pH}$. Cara kerja alat tersebut yaitu dengan menghubungkan kedua bagian dari $\mathrm{pH}$ meter tersebut, kemudian memasukkan alat pendeteksi nilai $\mathrm{pH}$ ke dalam 
air manisan mangga. Kemudian nilai $\mathrm{pH}$ dari manisan mangga tersebut dapat dilihat pada layar. Pengujian dilakukan sebanyak 3 kali dengan cara yang sama.

\section{Uji Massa Jenis}

Untuk uji massa jenis dilakukan dengan memasukkan air manisan mangga udang sebanyak $25 \mathrm{ml}$ ke dalam gelas ukur. Sebelumnya gelas ukur ditimbang dengan neraca digital. massa dari gelas ukur untuk diketahui massanya. Kemudian memasukkan air manisan ke dalam gelas ukur dan ditimbang dengan neraca digital. Pengujian massa jenis dilakukan sebanyak 3 kali, maka digunakan persamaan 2.1.

$\rho=\frac{m}{v}$

\section{Uji Viskositas}

Uji viskositas dilakukan dengan menggunakan viskometer ostwald, Penggunaan viskometer Ostwald yaitu, dengan memasukkan air manisan mangga pada tabung viskometer kemudian dihisap dengan bola penghisap yang berada pada lubang agar masuk ke sampai batas A kemudian bola penghisap udara ditekan agar air turun dari A hingga batas B. dalam proses pelepasan bola penghisap udara dilakukan juga pengamatan lamanya waktu air (T1) turun dari A hingga batas B dengan stopwatch.

Selanjutnya proses tersebut dilakukan untuk jenis cairan lain sebagai pembanding, dalam penelitian ini digunakan aquadest sebagai cairan lain. Kemudian mencatat waktu lamanya air aquadest turun (T2). Jika kedua waktu dari air mainisan mangga udang dan aquadest telah didapat, Kemudian dihiting dengan menggunakan persamaan (2.2) [11].

$$
\frac{\eta_{1}}{\eta_{2}}=\frac{T_{1}}{T_{2}} \frac{\rho_{1}}{\rho_{2}}
$$

Dengan $\gamma_{-} 1$ adalah massa jenis air 1 dan $\gamma_{-} 2$ merupakan massa jenis manisan yang dicari. Dan untuk mendapatkan nilai viskositas maka nilai $\mathrm{t}$ (waktu) yang diuji dalam penelitian ini.

Dengan $\eta_{1}$ adalah nilai viskositas manisan mangga udang, $\eta_{2}$ adalah viskositas dari aquadest $\rho_{1}$ adalah massa jenis manisan mangga udang dan $\rho_{2}$ merupakan massa jenis manisan yang aquadest. Kemudian untuk T1 adalah waktu dari manisan dan T2 waktu dari aquadest.

\section{Uji Oxidation Reduction Potential (ORP)}

Uji ORP juga dilakukan dengan menggunakan alat ORP meter. Alat ini memiliki cara penggunaan yang sama dengan $\mathrm{pH}$ meter. Perbedaanya hanya dengan mengganti kabel (alat) pendeteksi nilai pH dengan ORP. Dan nilai ORP juga dilihat pada layar yang dihubungkan dengan alat pendeteksi nilai ORP tersebut. Pengujian dilakukan pengulangan sebanyak 3 kali.

\section{Uji Total Disolve Solid (TDS)}

Uji TDS juga dilakukan dengan menggunakan alat TDS meter. Alat ini juga memiliki cara penggunaan yang sama dengan $\mathrm{pH}$ dan ORP meter. Perbedaanya hanya dengan mengganti kabel (alat) pendeteksi nilai $\mathrm{pH}$ atau ORP dengan TDS. Dan nilai TDS juga dapat dilihat pada layar. Pengujian dilakukan pengulangan sebanyak 3 kali.

\section{Uji Konduktivitas}

Untuk uji Konduktivitas dilakukan menggunakan alat yang sama dengan TDS meter. Dan untuk mengetahui nilai konduktivitas dilakukan dengan cara menekan tombol function hingga menjadi fungsi konduktivitas. Kemudian setelah fungsi terganti maka nilai konduktivitas dapat dilihat pada layar. Pengujian konduktivitas juga dilakukan sebanyak 3 kali.

\section{Uji Resistivitas}

Sama dengan uji konduktivitas, uji resistivitas juga dilakukan menggunakan alat yang sama dengan TDS meter. Dan caranya juga sama yaitu dengan menekan tombol function hingga menjadi fungsi resistivitas. Kemudian nilai resistivitas dapat dilihat pada layar. Pengujian resistivitas juga dilakukan sebanyak 3 kali.

\section{Uji Rasa (Organoleptik)}

Uji organoleptik (rasa) yang dilakukan adalah uji kesukaan terhadap rasa, berdasarkan tingkat kesukaan konsumen. Pengujian dilakukan oleh 
10 orang panelis pria dan wanita dengan usia 30 hingga 40 tahun. Kemudian panelis tersebut akan memberikan penilaian berdasarkan rasa dari manisan tersebut, dengan penilaian suka dan tidak suka.

\section{HASIL DAN PEMBAHASAN}

Hasil dari penelitian mengenai uji $\mathrm{pH}$ dan karakteristik fisis manisan buah mangga udang dengan beberapa sampel manisan ditunjukkan pada beberapa gambar di bawah ini.

\section{pH}

Gambar 3. berikut menunjukkan hasil $\mathrm{pH}$ yang merupakan perbandingan beberapa sampel manisan mangga udang dan lamanya penyimpanan. Gambar 3 menunjukkan jika nilai pada semua variasi manisan mangga menurun pada hari kedua dan ketiga.

Menurunnya nilai $\mathrm{pH}$ tersebut menandakan jika manisan semakin asam berdasarkan lamanya penyimpanan. Akan tetapi nilai $\mathrm{pH}$ kembali naik pada hari keempat. Naiknya nilai pH pada hari keempat dapat disebabkan karena perbedaan suhu pada saat pengambilan [2].

Nilai $\mathrm{pH}$ pada manisan A tersebut cenderung naik. Hal tersebut dapat disebabkan karena pada manisan tersebut tidak ditambahkan dengan pemanis buatan. Dimana pemanis buatan itu sendiri merupakan bahan tambahan yang dapat menyebabkan rasa manis pada makanan. Pemanis buatan adalah jenis pemanis yang dihasilkan dari bahan-bahan kimia. Dengan tidak ditambahkan pemanis buatan pada manisan A, maka manisan A tidak mengandung bahan-bahan kimia.

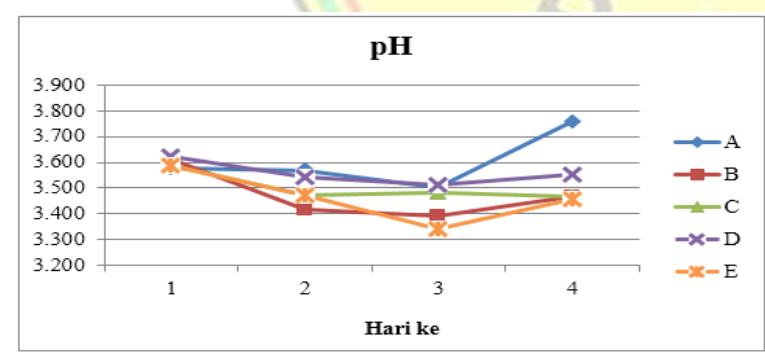

Gambar. 3. Hubungan Nilai pH Air Manisan Mangga dengan Lamanya Penyimpanan

Sehingga tidak memberi pengaruh pada nilai pH manisan A. Pada manisan lainnya nilai $\mathrm{pH}$ cenderung menurun dikarenakan pada manisan tersebut ditambahkan dengan pemanis buatan.
Sehingga nilai $\mathrm{pH}$ semakin asam berdasarkan lamanya penyimpanan [3].

Selain itu suhu juga menjadi salah satu faktor penyebab menurunnya nilai $\mathrm{pH}$ pada manisan $\mathrm{B}$, C, D dan E. Karena semakin turun suhu maka nilai $\mathrm{pH}$ akan semakin rendah. Perubahan $\mathrm{pH}$ ini juga dapat disebabkan oleh adanya mikroorganisme.

Mikroorganisme yang dapat tumbuh pada kisaran $\mathrm{pH}$ manisan (pH 3 - 6) antara lain khamir (dapat tumbuh pada $\mathrm{pH}$ rendah $2,5-8,5$ ) dan kapang (mempunyai pH optimum $5-7$, tetapi masih dapat tumbuh pada $\mathrm{pH} 3-8,5$ ) [2].

\section{Massa Jenis}

Nilai massa jenis dari manisan mangga dengan lamanya penyimpanan dapat dilihat pada Gambar 4. Manisan B pada Gambar tersebut memiliki nilai massa jenis yang berbeda dengan manisan lainnya. Nilai massa jenis manisan tersebut menurun signifikan pada hari kedua kemudian naik pada hari ketiga dan cenderung stabil pada hari berikutnya. Nilai massa jenis manisan B tersebut berbeda dengan variasi manisan lainnya. Sedangkan Nilai untuk manisan lain cenderung stabil pada setiap penyimpanan.

Perbedaan nilai pada manisan B dapat disebabkan karena penambahan jumlah pemanis buatan yang lebih banyak dibandingkan dengan manisan lainnya. Nilai massa jenis pada yang terlihat pada Gambar di atas untuk manisan A, C, D dan E cenderung sama pada setiap harinya.

Untuk manisan B nilai massa jenis sangat bervariasi pada setiap pengambilan. Dan pada manisan $\mathrm{B}$, hari pertama pengambilan nilai massa jenis bernilai tinggi dan menurun dihari berikutnya [3].

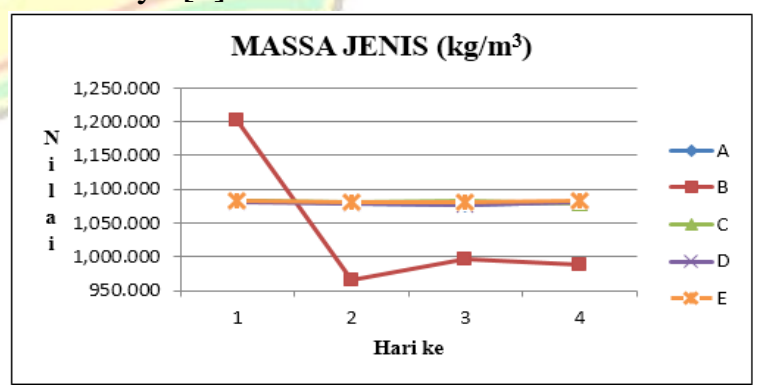

Gambar. 4. Hubungan Nilai Massa Jenis Air Manisan Mangga dengan Lamanya Penyimpanan. 


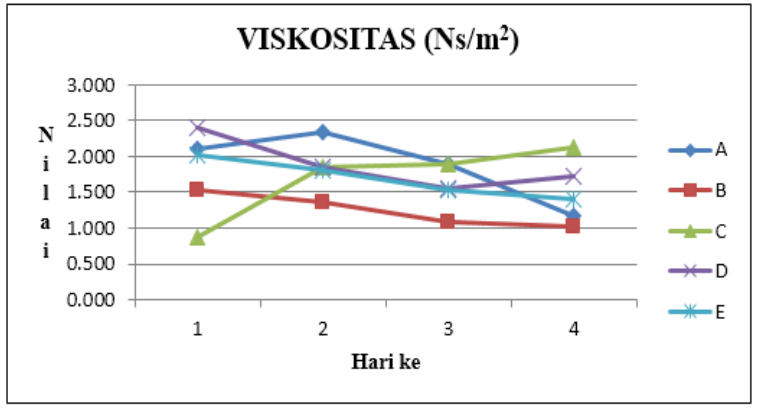

Gambar. 5. Hubungan Nilai Viskositas Air Manisan Mangga Dengan Lamanya Penyimpanan

Nilai massa jenis yang sama pada setiap pengambilan untuk manisan $\mathrm{A}, \mathrm{C}, \mathrm{D}$ dan $\mathrm{E}$, dapat dipengaruhi oleh penambahan jumlah pemanis buatan. Dimana pada masing-masing manisan tersebut penambahan jumlah pemanis tidaklah terlalu besar jika dibandingkan dengan manisan B. Dengan demikian nilai massa jenis dari manisan mangga dapat dipengaruhi oleh jumlah penambahan pemanis buatan [3].

\section{Viskositas}

Gambar 5. di atas ini menunjukkan nilai viskositas manisan mangga dengan lamanya penyimpanan. Nilai viskositas yang ditunjukkan pada gambar tersebut cenderung menurun stabil untuk manisan A, B, D dan E pada setiap harinya. Hasil yang berbeda ditunjukkan oleh manisan C, dimana nilai dihari pertama rendah dan naik signifikan dihari kedua kemudian naik stabil dihari berikutnya hingga hari terakhir. Perbedaan nilai viskositas pada manisan mangga dapat disebabkan oleh naik dan turunnya suhu pada saat pengambilan data. Dimana antara suhu dan viskositas berbanding terbalik.

Jika semakin tinggi suhu pengambilan viskositas, maka akan semakin rendah nilai viskositas pada manisan tersebut. Dan dalam hal ini penambahan pemanis buatan tidak memberikan pengaruh yang besar pada nilai viskositas $[10,11]$.

\section{Oxidation Reduction Potential (ORP)}

Nilai ORP dari manisan mangga udang ditunjukkan pada Gambar 6. ORP merupakan suatu kemampuan cairan dalam membunuh bakteri dalam cairan itu sendiri. Semakin tinggi nilai ORP suatu cairan maka akan semakin cepat waktu cepat mengalami kerusakan (basi) [12].

Gambar tersebut menunjukkan jika manisan B, D dan E signifikan menurun dihari kedua dari hari pertama. Kemudian nilai kembali naik dan turun signifikan di hari ketiga dan keempat. Untuk nilai ORP manisan A cenderung stabil pada setiap harinya.

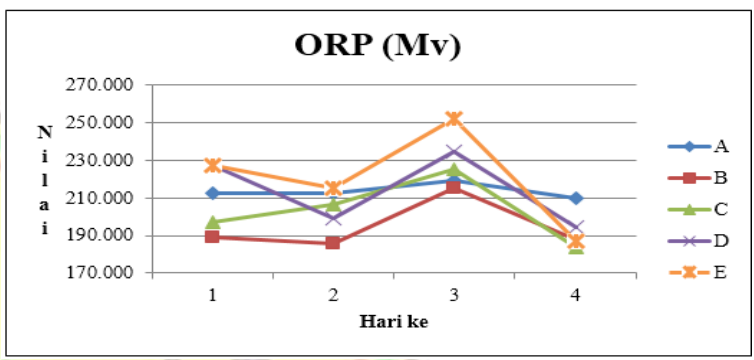

Gambar. 6. Hubungan Nilai ORP Air Manisan Mangga Dengan Lamanya Penyimpanan

Sedangkan pada manisan $\mathrm{C}$ nilai ORP cenderung naik stabil dari hari pertama hingga hari ketiga dan menurun signifikan pada hari keempat. Sampel F merupakan sampel dengan penambahan asam benzoat paling banyak. Nilai massa jenis sampel $F$ cenderung berubah-ubah pada setiap pengukuran nilai massa jenis.

Pada manisan A, nilai ORP cenderung sama (tidak ada perubahan) dikarenakan tidak ditambahkan dengan pemanis buatan. Sedangkan untuk manisan B, manisan mangga ditambahkan dengan pemanis buatan dengan jumlah yang cukup besar dibandingkan dengan manisan lainnya. Sehingga dengan penambahan jumlah pemanis buatan yang besar mampu memberikan pengaruh pada nilai ORP manisan mangga. Dengan demikian semakin banyak jumlah pemanis buatan yang ditambahkan maka akan semakin rendah nilai ORP pada manisan tersebut. Sehingga dengan demikian, maka pemanis buatan mempengaruhi nilai ORP pada manisan mangga udang [12].

\section{Total Disolve Solid (TDS)}

Gambar 7 menunjukkan hasil dari nilai TDS manisan mangga dengan lamanya penyimpanan. Gambar tersebut menunjukkan jika nilai TDS pada manisan B berbeda dengan sampel lainnya. 
Nilai TDS pada sampel tersebut cenderung naik stabil pada setiap harinya.

Total Disolve Solid (TDS) merupakan suatu padatan yang terdapat didalam suatu cairan. Nilai pada manisan B cukup besar dibandingkan nilai TDS manisan lainnya. Sedangkan hasil yang cukup jauh berbeda terdapat pada manisan A. Nilai TDS manisan A cukup rendah dibandingkan manisan yang lainnya. Dan nilai tersebut cenderung naik stabil pada setiap harinya. Untuk manisan $\mathrm{C}, \mathrm{D}$ dan $\mathrm{E}$ nilai naik signifikan dihari kedua dari hari pertama dan menurun stabil dihari berikutnya hingga hari keempat (hari terakhir).

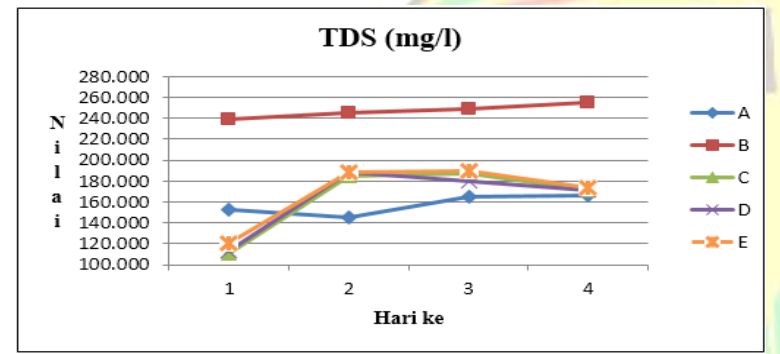

Gambar. 7. Hubungan TDS Air Manisan Mangga

Dengan Lamanya Penyimpanan

Dalam Gambar tersebut dapat dilihat jika nilai TDS untuk semua manisan cenderung naik. Dan untuk nilai TDS tertinggi dapat dilihat pada manisan $B$, dimana manisan $B$ merupakan manisan dengan penambahan pemanis buatan sebanyak 7 gram. Kecenderungan nilai TDS tersebut dapat disebabkan karena pengaruh dari bahan yang dipakai dalam pembuatan manisan mangga tersebut. Dimana bahan tersebut tidak terlarut dengan sempurna. Faktor tingginya nilai TDS pada manisan B yaitu karena jumlah pemanis buatan yang ditambahkan pada manisan tersebut cukup besar. Sehingga mampu memberikan pengaruh terhadap nilai TDS pada manisan tersebut [13].

\section{Salinitas}

Nilai salinitas manisan mangga ditunjukkan pada Gambar 8 di bawah ini. Salinitas merupakan kandungan garam yang terkandung dalam manisan mangga tersebut. Sama halnya denga nilai TDS di atas, nilai salinitas juga cenderung naik untuk semua sampel. Dan untuk nilai salinitas tertinggi terdapat pada manisan B.
Nilai salinitas yang ditunjukkan pada gambar tersebut dapat dilihat jika manisan B memiliki nilai tertinggi dibandingkan dengan sampel lainnya. Nilai pada manisan B tersebut cenderung naik stabil pada setiap harinya. Nilai terendah terdapat pada manisan A dengan nilai yang cenderung menurun dihari kedua dan stabil dihari berikutnya hingga hari keempat (terakhir).

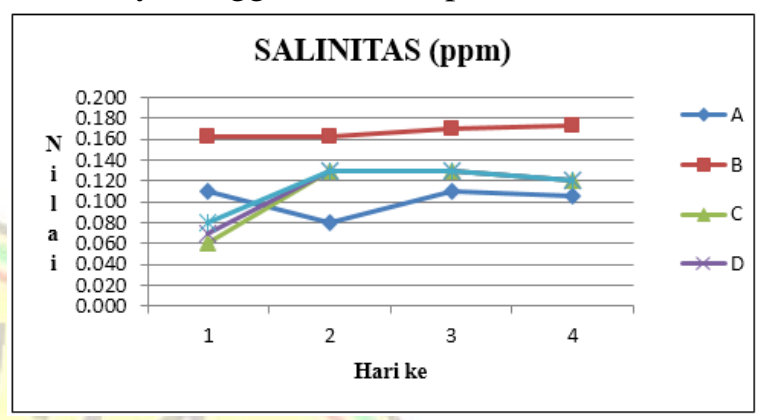

Gambar. 8. Hubungan Salinitas Air Manisan Mangga Dengan Lamanya Penyimpanan

Berubahnya nilai salinitas dapat dipengaruhi oleh nilai $\mathrm{pH}$ dari manisan tersebut. Dan manisan mangga yang mengandung senyawa asam kuat dan basa kuat akan memiliki sifat netral dengan rasa yang asin [16].

\section{Konduktivitas}

Konduktivitas merupakan kemampuan suatu cairan dalam menghantarkan arus listrik.Gambar 9 di bawah ini menunjukkan nilai konduktivitas manisan mangga dengan lamanya waktu penyimpanan. Gambar tersebut menunjukkan nilai konduktivitas manisan A yang cenderung naik stabil hingga hari keempat (terakhir). Untuk manisan $B$ yang memiliki nilai tinggi dibandingkan yang lain. Nilai tersebut naik cukup signifikan pada hari kedua dan naik stabil pada hari berikutnya.

Kemudian nilai konduktivitas manisan $\mathrm{C}$ naik signifikan pada hari kedua dan menurun stabil pada hari ketiga. Dihari keempat nilai konduktivitas manisan $\mathrm{C}$ cenderung menurun signifikan dari hari sebelumnya.Nilai pada manisan lainnya seperti D dan E naik signifikan pada hari kedua dari hari pertama dan cenderung stabil di hari ketiga. Akan tetapi dihari keempat turun signifikan untuk manisan $\mathrm{D}$ dan naik signifikan untuk manisan E. 
Gambar tersebut terlihat jika nilai konduktivitas pada semua manisan cenderung naik. Selain itu nilai konduktivitas untuk semua manisan juga cukup tinggi, yaitu berada pada rentang $166-376 \mathrm{Ohm}^{-1}$.

Dan nilai konduktivitas tertinggi terdapat pada manisan B, yaitu manisan mangga dengan pemanis buatan sebanyak 7 gram. Dimana nilai tersebut berada pada rentang $287-376 \mathrm{Ohm}^{-1}$ [15].

Pada manisan A nilai konduktivitas cukup tinggi pada setiap pengambilan. Sedangkan manisan C, D dan E nilai konduktivitas masih berada di bawah nilai manisan A. Akan tetapi dengan penambahan pemanis yang cukup besar pada manisan B mampu meningkatkan nilai konduktivitas pada manisan tersebut. Dengan demikian semakin besar jumlah pemanis buatan yang ditambahkan pada manisan mangga, maka akan semakin tinggi juga nilai konduktivitasnya [15].

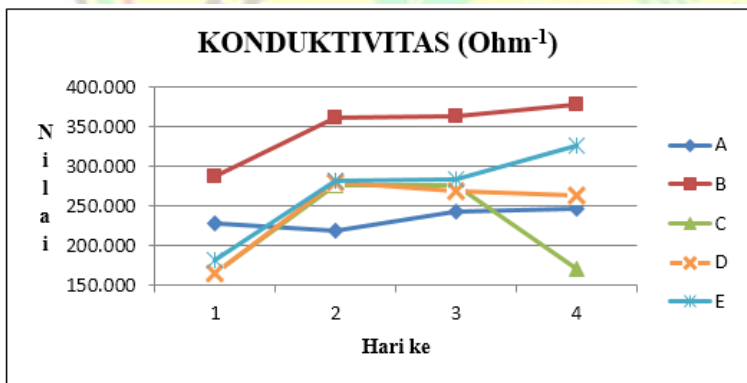

Gambar. 9. Hubungan Konduktivitas Air Manisan Mangga Dengan Lamanya Penyimpanan

Penambahan asam benzoat mempengaruhi nilai ORP lebih tinggi. Sedangkan tanpa penambahan asam benzoat nilai rendah dari hari pertama hingga keenam (terakhir). Akan tetapi, semakin tinggi nilai ORP maka semakin mudah reaksi oksidasi terjadi dan semakin banyak membran sel pada air manisan Mangga yang rusak dan mati. Sehingga air manisan Mangga menjadi lebih cepat basi (rusak) [18].

\section{Resistvitas}

Resisitivitas merupakan kebalikan dari konduktivitas, yaitu kemampuan suatu cairan dalam menghambat atau memperlambat aliran listrik. Nilai dari resisitivitas manisan mangga dapat dilihat pada Gambar 10 di bawah ini.

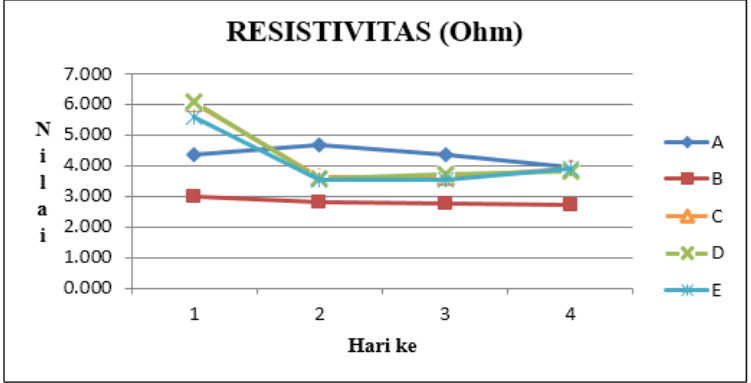

Gambar. 10. Hubungan Resistvitas Air Manisan Mangga Dengan Lamanya Penyimpanan

Nilai resistivitas yang ditunjukkan pada gambar tersebut berbanding terbalik dengan nilai konduktivitas di atas. Pada manisan A nilai cukup tinggi dibandingkan dengan manisan lainnya dan nilai cenderung stabil pada setiap harinya. Kemudian manisan B memiliki nilai resistivitas terendah dibandingkan dengan manisan lainnya. Dan nilai resistivitas cenderung menurun stabil hingga hari keempat. Berikutnya yaitu manisan $\mathrm{C}, \mathrm{D}$ dan $\mathrm{E}$ nilai resistivitas turun signifikan dihari kedua dari hari pertama dan cenderung stabil hingga hari terakhir.

Dan nilai resistivitas pada semua manisan kecil yaitu pada rentang 2,6 - 6,0 Ohm. Dan nilai resistivitas terendah terdapat pada manisan $B$. Dimana nilai manisan B berada pada rentang 2,6 - 2,9 Ohm. Dengan demikian hasil dari kedua nilai tersebut membuktikan tentang teori keduanya. Dimana jika nilai konduktivitas tinggi, maka nilai resistivitas akan rendah dan begitu juga sebaliknya [16].

\section{Rasa}

Gambar 11 menunjukkan hasil rata-rata dari uji organoleptik berupa rasa yang dilakukan oleh 10 orang panelis dengan pilihan rasa $1=$ suka dan $2=$ tidak suka. Gambar 12, 13, 14 dan 15 menunjukkan jika pada sampel A dihari pertama hingga hari ketiga panelis menyukai rasa dari sampel manisan tersebut. Kemudian dihari keempat manisan sudah tidak disukai lagi. Selanjutnya Gambar 16, 17, 18 hingga 22 menunjukkan dari hasil uji rasa sampel B dan C. 


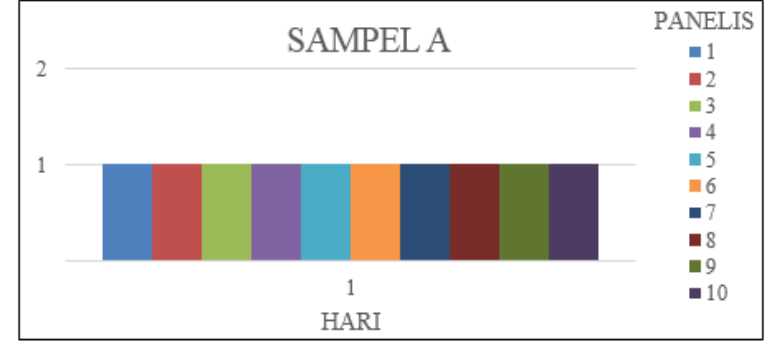

Gambar. 11. Hasil Uji Rasa Sampel A hari Pertama

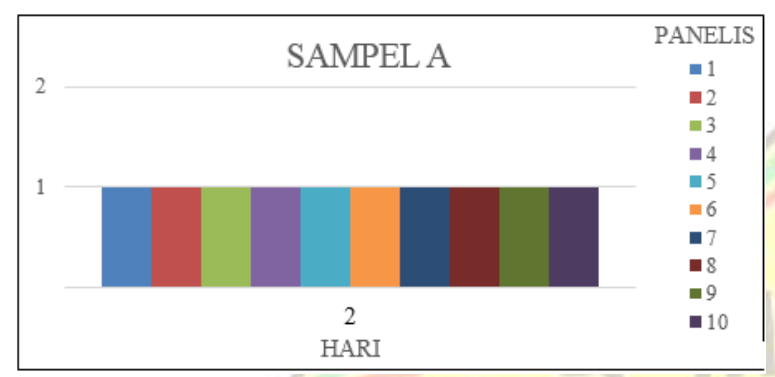

Gambar. 12. Hasil Uji Rasa Sampel A hari Kedua

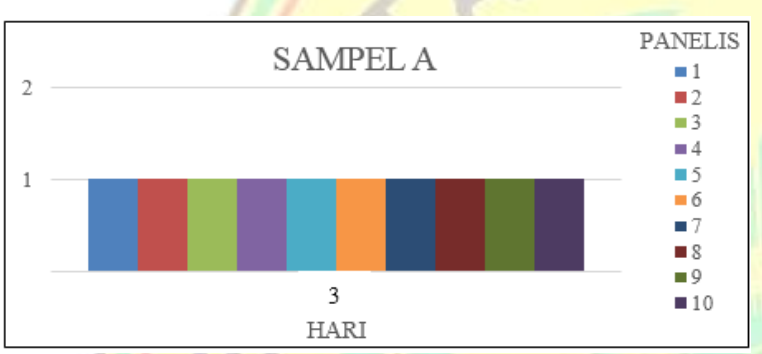

Gambar. 13. Hasil Uji Rasa Sampel A hari Ketiga

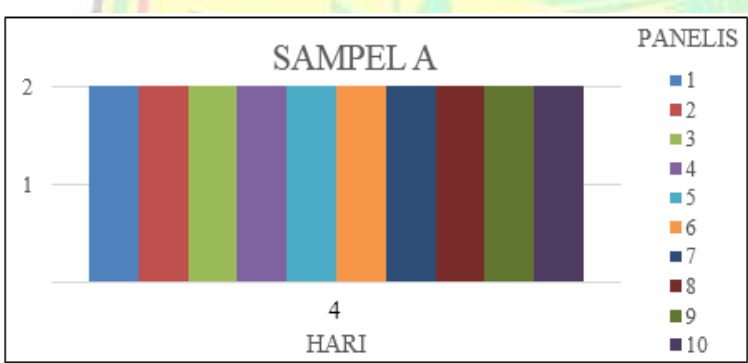

Gambar. 14. Hasil Uji Rasa Sampel A hari Keempat

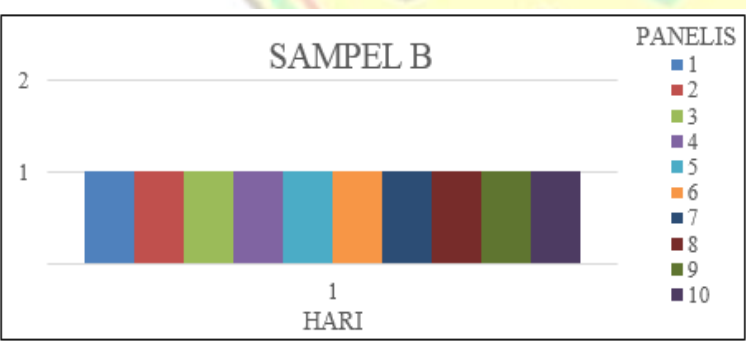

Gambar. 15. Hasil Uji Rasa Sampel B hari Pertama

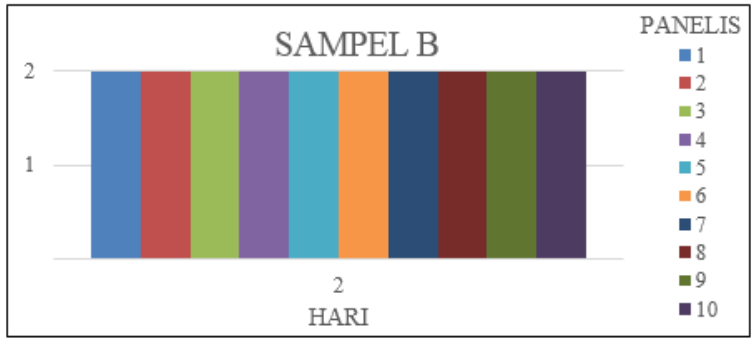

Gambar. 16. Hasil Uji Rasa Sampel B hari Kedua

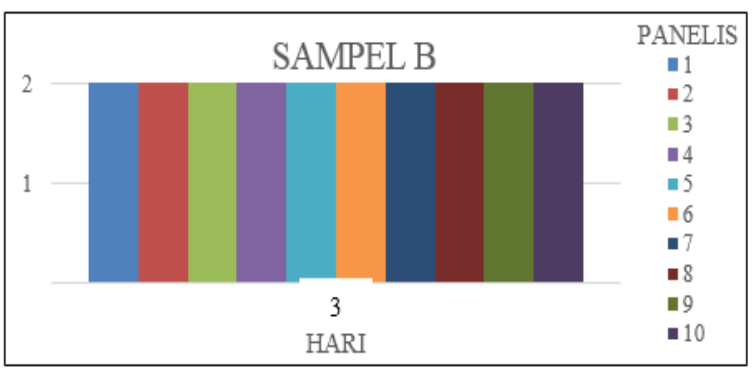

Gambar. 17. Hasil Uji Rasa Sampel B hari Ketiga

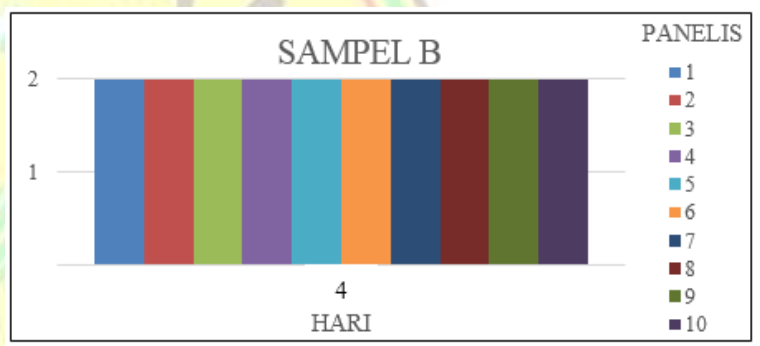

Gambar. 18. Hasil Uji Rasa Sampel B hari Keempat

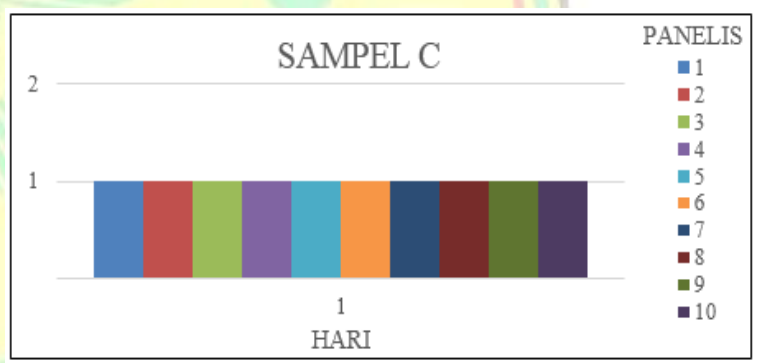

Gambar. 19. Hasil Uji Rasa Sampel C hari Pertama

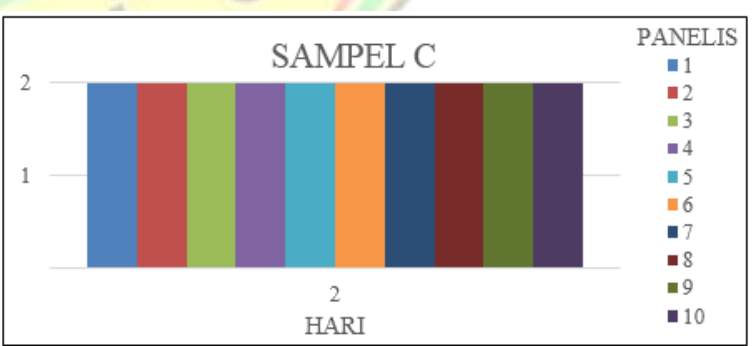

Gambar. 20. Hasil Uji Rasa Sampel C hari Kedua 


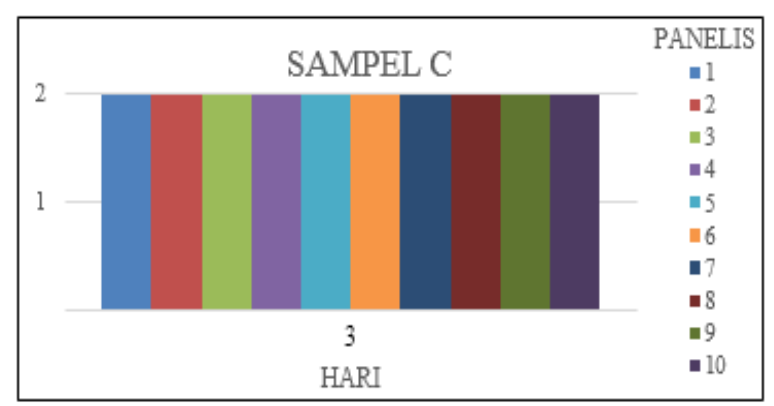

Gambar. 21. Hasil Uji Rasa Sampel C hari Ketiga

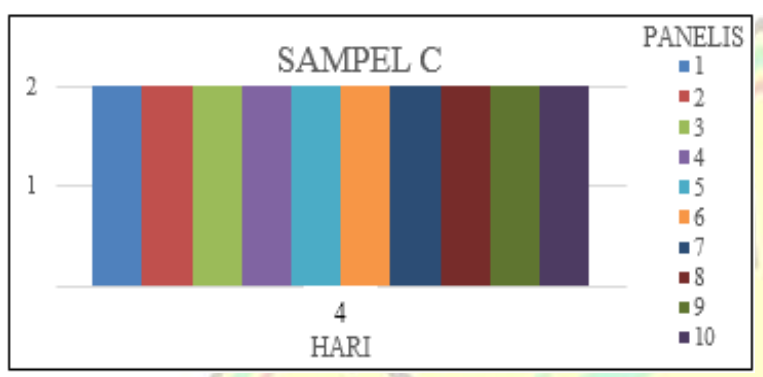

Gambar. 22. Hasil Uji Rasa Sampel C hari Keempat

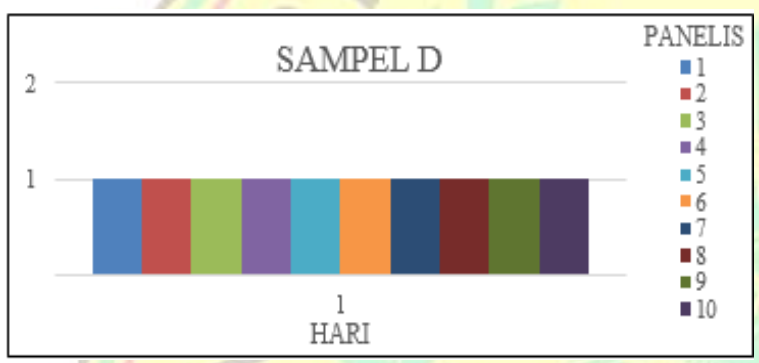

Gambar. 23. Hasil Uji Rasa Sampel D hari Pertama

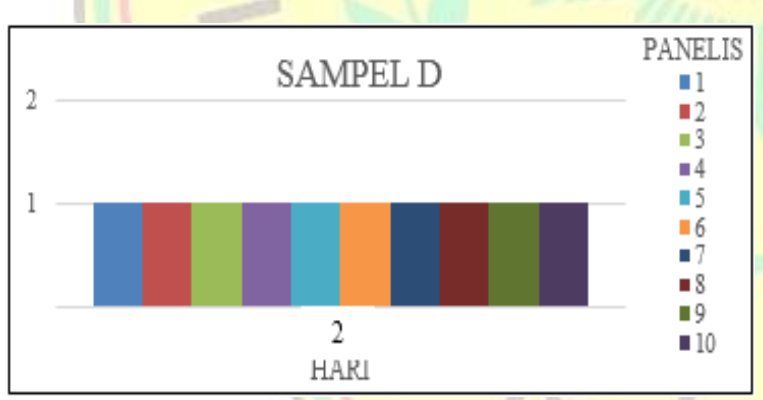

Gambar. 24. Hasil Uji Rasa Sampel D hari Kedua

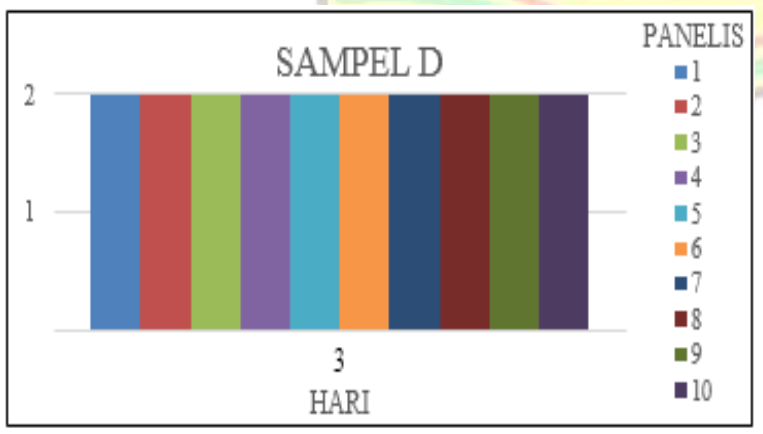

Gambar. 25. Hasil Uji Rasa Sampel D hari Ketiga

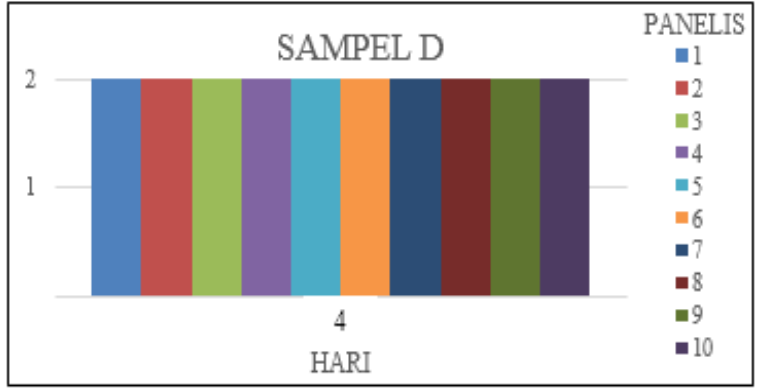

Gambar. 26. Hasil Uji Rasa Sampel D hari Keempat

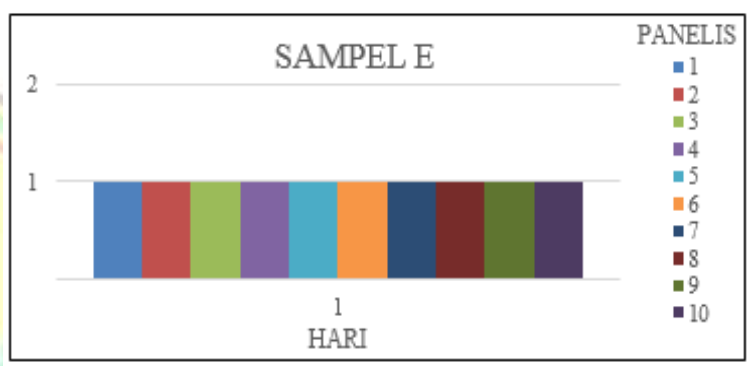

Gambar. 27. Hasil Uji Rasa Sampel E hari Pertama

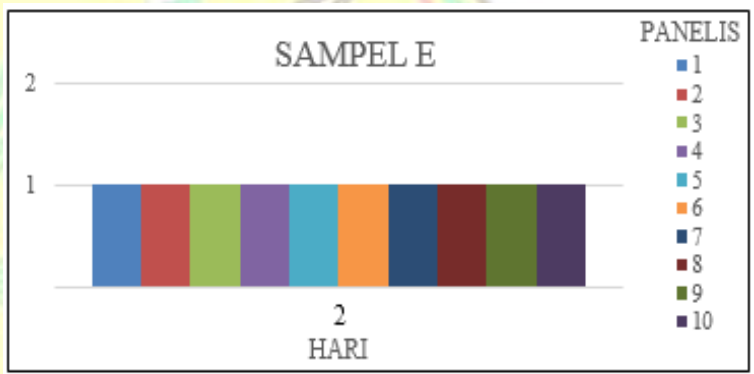

Gambar. 28. Hasil Uji Rasa Sampel E hari Kedua

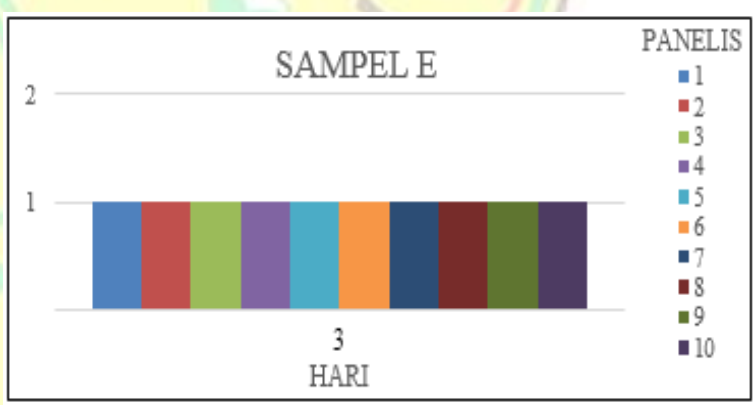

Gambar. 29. Hasil Uji Rasa Sampel E hari Ketiga

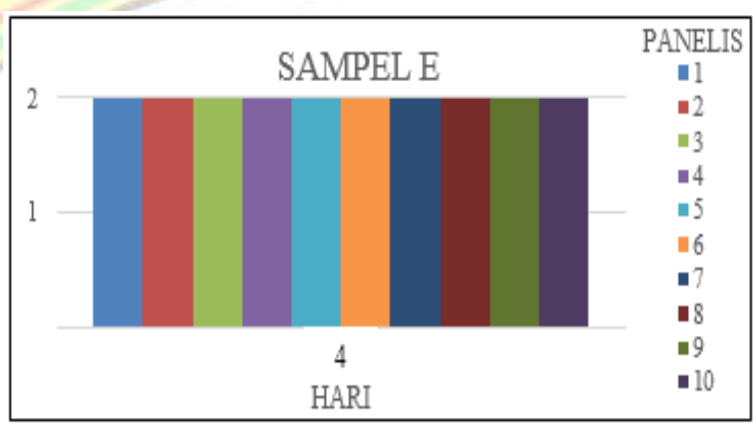

Gambar. 30. Hasil Uji Rasa Sampel E hari Kempat 
Pada gambar tersebut terlihat jika kedua sampel manisan hanya disukai dihari pertama saja. Sedangkan hari berikutnya hingga hari terakhir kedua sampel manisan tersebut tidak disukai oleh para panelis lagi.

Pada Gambar 23, 24, 25 dan 26 merupakan hasil dari uji rasa sampel D. Gambar tersebut menunjukkan jika sampel manisan disukai oleh panelis pada hari pertama dan kedua. Kemudian untuk hari ketiga dan keempat panelis sudah tidak menyukai sampel dari manisan tersebut.

Untuk Gambar 27, 28, 29 dan 30 menunjukkan hasil uji rasa dari sampel manisan E. Hasil yang ditunjukkan oleh gambar tersebut sama denga sampel A, dimana panelis menyukai rasa manisan hingga hari ketiga. Hal tersebut dikarenakan jumlah penambahan pemanis buatan pada sampel E lebih sedikit dibandingkan dengan sampel lainnya.

Berdasarkan dari semua gambar tersebut, maka semua manisan pada hari pertama disukai oleh semua panelis. Hal tersebut karena manisan baru sehingga belum semua pemanis dan mangga terlarut dengan sempurna. Selanjutnya manisan B dan $\mathrm{C}$ mulai tidak disukai pada hari kedua. Hal tersebut dapat disebabkan karena penambahan manisan buatan yang cukup banyak, sehingga menyebabkan rasa pahit pada manisan tersebut. Kemudian pada hari ketiga selain manisan B dan $\mathrm{C}$, manisan D juga tidak disukai. Hal tersebut disebabkan karena manisan semakin terasa pahit dan ada sedikit rasa asam. Hari selanjutnya, tidak ada satupun manisan yang disukai oleh panelis. Pada hari keempat manisan semakin asam dan terasa pahit. Hal tersebut disebabkan karena penambahan pemanis buatan pada manisan tersebut [17].

\section{KESIMPULAN DAN SARAN Kesimpulan}

Dari hasil yang telah diperoleh maka dapat diambil beberapa kesimpulan diantaranya;

1. Pada uji $\mathrm{pH}$, nilai $\mathrm{pH}$ terbaik terdapat pada sampel A, yaitu sampel dengan variasi $1 \mathrm{~kg}$ mangga udang, 650 gram gula, 2 liter air, 100 gram garam dan 1 gram pewarna. Dimana nilai $\mathrm{pH}$ pada sampel A cenderung meningkat berdasarkan lamanya penyimpanan, dan nilai sampel tersebut yaitu 3,75 .

2. Pada uji fisis untuk nilai massa jenis, ORP, dan konduktivitas, nilai terbaik terdapat pada sampel B, yaitu sampel dengan variasi $1 \mathrm{~kg}$ mangga udang, 650 gram gula, 7 gram pemanis buatan, 2 liter air, 100 gram garam dan 1 gram pewarna, dengan masing-masing nilai $1202 \mathrm{~kg} / \mathrm{m} 3,187 \mathrm{Mv}$ dan 376 Ohm.

3. Untuk hasil uji fisis lain yaitu viskositas, TDS, salinitas dan resistivitas nilai terbaik terdapat pada sampel A dengan variasi $1 \mathrm{~kg}$ mangga udang, 650 gram gula, 2 liter air, 100 gram garam dan 1 gram pewarna, dengan masingmasing nilai yaitu 3,29 Ns/m2, $145 \mathrm{~g} / \mathrm{l}, 0,08$ ppt dan 4,69 Ohm-1.

4. Dari hasil uji organoleptik yang mencakup rasa, manisan dengan penambahan pemanis buatan lebih cepat asam dibandingkan tanpa penambahan. Selain itu manisan dengan penambahan pemanis buatan terdapat rasa pahit pada manisan tersebut.

\section{DAFTAR PUSTAKA}

Sulistyaningrum Ferida. 2012. Analisis Sifat Fisik dan Organoleptik Keripik Buah Mangga (Mangifera Indica L).Laporan Tugas Akhir. Universitas Diponegoro. Semarang.

Tentang Budidaya Pertanian. 2000. Mangga. Kantor Deputi Menegristek Bidang Pendayagunaan dan Pemasyarakatan Ilmu Pengetahuan dan Teknologi.

[Soetanto, E. 1996. Manisan Buah-buahan II. Yogyakarta: Penerbit Kansius.

[Hadju, Nurain A. 2012. Analisis Zat Pemanis Buatan Pada Minuman Jajanan Yang Dijual Di Pasar Tradisional Kota Manado. Manado. Jurnal. Jurusan Teknologi Pertanian Fakultas Pertanian Universitas Samratulangi.

Dwiyanti, P. dan Wazyka, A. 2009. Sifat Antioksidan, Sifat Kimia dan Sifat Fisik, Manisan Basah dari Kunyir Putih (Curcuma mangga Val). Agritech, Vol. 29, No.3.

www.naturindonesia.com/tanamanpangan/tanaman-buah-dan-sayuran- 
m/763-mangga-udang.html. Mangga

Udang. Dikunjungi 10 Januari 2013.

Budianto, Anwar. 2008. Metode Penentuan Koefisien Kekentalan Zat Cair Dengan Menggunakan Regresi Linier Hukum Stokes. Seminar Nasional SDMteknologi Nuklir. Yogyakarta, 25-26 Agustus 2008. ISSN 1978-0176.

Fitriyanto, dkk. 2013. Kajian Viskositas Dan Berat Jenis Susu Kambing Peranakan Etawa (Pe) Pada Awal, Puncak Dan Akhir Laktasi. Purwokerto. Fakultas Peternakan, Universitas Jendral Soedirman Purwokerto.

Hazmi Ariadi, dkk. 2012. Penghilangan
Mikroorganisme dalam Air Minum dengan Dielectric Barrier Discharge. Padang.Jurusan Teknik Kimia, Fakultas Teknologi Industri, Universitas Bung Hatta

Rahma Siti. 2009. Pencitraan Dua Dimensi Data Resistivity Dan Induced Polarization Untuk Mendelineasi Deposit Emas Sistem Epithermal Di Daerah "X". Jakarta. Fakultas Matematka Dan Ilmu Pengetahuan Alam, Univerrsitas Indonesia.

Zuhra Cut. F. 2006. Flavor (Cita Rasa). Medan. Karya Ilmiah Universitas Sumatra Utara. 
